EPiC Series in Engineering
Volume 3, 2018, Pages 1424-1434
HIC 2018. 13th International
Conference on Hydroinformatics

\title{
Climate Changes Impacts on Groundwater Recharge in UAE
}

\author{
Mohamed Mostafa Mohamed \\ ${ }^{1}$ Department of Civil and Environmental Engineering, \\ United Arab Emirates University, Al Ain, P.O.BOX 17555, UAE. \\ m.mohamed@uaeu.ac.ae
}

\begin{abstract}
Despite the continuous increase in water supply from desalination plants in the UAE, groundwater remains the major source of fresh water satisfying domestic and agricultural demands. Additionally, groundwater has always been considered as a strategic water source towards groundwater security in the country. Quantification of groundwater recharge is a prerequisite for efficient and sustainable groundwater resources management in arid regions. Therefore, groundwater recharge from the ephemeral Wadi beds and subsurface flow from mountainous valley beds play an important role in water management. Although, both surface and groundwater resources in UAE are scarce; the anticipated climate change impacts could make these resources even scarcer. As such, the main aim of this paper is to assess the potential impacts of future climate variability and change on groundwater recharge in the eastern region of UAE. This paper will explore rainfall characteristics in the region, their projections and their impacts on Wadi hydrology and groundwater recharge processes. Another objective of the study is to identify groundwater recharge regions to the shallow unconfined groundwater aquifer in the northeastern part of Abu-Dhabi Emirate. Outcomes of this study will help to accurately estimate current and future sustainable extraction rates, assess groundwater availability, and identify pathways and velocity of groundwater flow as crucial information for determining the best locations for artificial recharge.
\end{abstract}




\section{Introduction}

Abu Dhabi Emirate has a hyper-arid climate with less than $100 \mathrm{~mm} /$ year of precipitation, a very high potential evaporation rate ( 2 to $3 \mathrm{~m} /$ year), a very low groundwater recharge rate (less than $4 \%$ of total annual water used) and no reliable, perennial surface water resources (Environment Agency-Abu Dhabi, 2009). Groundwater is the only conventional source of water in the Emirate of Abu Dhabi. Its share to the total fresh water supply in the Emirate is about $80 \%$. Other unconventional sources of fresh water in the Emirate are five sea water desalination plants $(17 \%)$ and wastewater reuse $(3 \%)$. Water is consumed in the domestic, industrial, commercial, agricultural, forestry and amenity sectors. With usage of $58 \%$ of total water production, the largest user sector of water is the agricultural sector. Water of drinking quality is supplied for domestic, industrial and commercial use and accounts for about $17 \%$ of the total water consumed. The current share of groundwater is estimated based on the estimated water demand in the Emirate and available production of the five desalination plants. The sustainable yield of a groundwater aquifer, however, depends mainly on how fast this aquifer is replenished. Yet, the continuously increasing demand puts more pressure on this already scarce source and threatens its quality (Sherif et al, 2011b; Elmahdi and Mohamed, 2012).

In arid regions, groundwater recharge from the ephemeral Wadi beds and subsurface flow from mountainous valley beds play an important role in water management. The quantification of groundwater recharge is a prerequisite for efficient and sustainable groundwater resources management in arid regions. Successful implementation of water resources planning requires knowledge of the space, time and frequency of rainfalls and their characteristics. The anticipated climate change in the region will increase the water demand and will affect the scarce groundwater resources more significantly. Rainfall in UAE is erratic both in time and space. In the eastern region of UAE, rainfall provides runoff to several Wadi systems cross over the border from Oman to provide preferential pathways for percolation and groundwater recharge. Changes in rainfall patterns might affect this groundwater recharge in the region. Groundwater systems are controlled by recharge processes, the geology of aquifer, residence time of groundwater and its discharge processes. The quality of groundwater is significantly influenced by groundwater residence time and type of recharge processes. Rainfall and runoff deficits have been observed in the UAE over the last couple of decades and consequently drought was persisted (Sherif et al., 2013). Annual rainfall in the region has reduced significantly since 1998 (Sherif et al., 2009, 2011a). Whilst there are few studies on rainfall characterization in the region, most of them are not linked to interactions between Wadi and groundwater hydrology. Significant knowledge gap exist on projection of rainfalls in the region and their influence on groundwater recharge processes.

Generally, estimation of groundwater recharge and discharge fluxes in unconfined systems in arid regions are difficult because of lack of knowledge on how to distribute water flux and vapor discharge (Imes and Wood, 2006). Early investigations of groundwater resources in the Abu Dhabi Emirate found that the surficial groundwater in the eastern region is one of the main sources of fresh groundwater (Sir Alexander Gibb and partners, 1969 and 1970; Hydroconsult, 1978). These studies warned that this aquifer has limited natural recharge and can be affected by pumping. Most of the recent natural recharge to this surficial aquifer is associated with the high precipitation near Oman Mountains across the northeastern border of the UAE. More recently, Symonds et al. (2005) identified the age of groundwater in some parts of this area between 12 and 45 years. Brook et al. (2006) identified development of aquifer vulnerability maps an important needed activity to protect groundwater resources in the Emirate. Development of such maps is obtained through identification of aquifer recharge areas. The strategic importance of these areas as a source of fresh groundwater must be considered in planning and management of water resources of the Emirate. Therefore, the 
major aim of this proposal is to develop age distribution map for the likely recharge areas of the surficial unconfined aquifer in the northeastern region of the Abu Dhabi Emirate. The proposed work in this proposal should be considered as a continuation of the work of Symonds et al. (2005) with the ultimate goal of developing complete groundwater age map across the eastern boundary of Abu Dhabi Emirate.

According to the IPCC's Third Assessment Report, arid and semi-arid regions of Asia are moderately to highly vulnerable to the effects of climate change. The effects of climate change on these regions may be among the first observed on the planet. Temperature projections in UAE in 2050, though containing significant uncertainty bounds, will be between about $1.6^{\circ} \mathrm{C}$ and $2.9^{\circ} \mathrm{C}$ warmer than they were over the period $1961-90$, and between $2.3^{\circ} \mathrm{C}$ and $5.9^{\circ} \mathrm{C}$ warmer by 2100 . Average annual rainfall in 2050 is projected to be between $20 \%$ less or up to $10 \%$ more than levels over the period 1961-90, and between $45 \%$ less or $22 \%$ more by 2100 . In addition to temperature and precipitation changes, the UAE will be affected by sea level rise associated with climate change. Global mean sea level is projected to rise by 9 to $88 \mathrm{~cm}$ between 1990 and 2100, with a central value of $48 \mathrm{~cm}$, for the full range of SRES scenarios. The combination of changes in temperature, precipitation and sea level pose significant risks to the UAE (Ministry of Energy-UAE, 2006).

A severe shortage of water resources associated with projected increases in air temperature as well as increases in potential evapotranspiration is likely to be the most significant impact of climate change in arid and semi-arid Asia (Ministry of Energy-UAE, 2006). The groundwater and limited surface water resources play an important role in a range of natural and economic sectors including agriculture, fisheries, livestock rearing, industry, forestry, as well as the residential sector. The presence of higher air temperatures associated with climate change would almost certainly increase the potential for more evapotranspiration and, in turn, decrease availability of surface and groundwater fed by run-off. This is important because any loss of freshwater supply will result in the need for additional desalination capacity or an increase in other alternative sources to satisfy demand. Such a circumstance would result in higher costs and additional energy consumption for water provision in the UAE. It could also lead to changes in the efficiency of groundwater pumping; as groundwater tables are lowered, the efficiency of groundwater extraction decreases, increasing the price of groundwater provision and direct changes to the agricultural and industrial sectors of the country.

An assessment of vulnerability and adaptation options is a critical component of the UAE's response to the threat of climate change. There are many levels at which the UAE is potentially vulnerable as its coastal zones, water resources, dryland ecosystems, agricultural production, human settlements, public health, and energy infrastructure are all considered to be highly sensitive to climatic changes.

\section{STUDY AREA}

The study area is located in the North-Eastern sector of Abu Dhabi Emirate extending from 313619 to 401268 in the East and from 2648825 to 2743980 in the North spanning an area about 8,340.24 km2. The geology of the area is characterized by the dominant presence of the recent deposits; minor Maastrichtian - Tertiary sediments in the south; Semail thrust and Semail Ophiolite in the north as part of Oman Mountains and Haybi and Hawasina thrust sheets in the East (Fig. 1). 

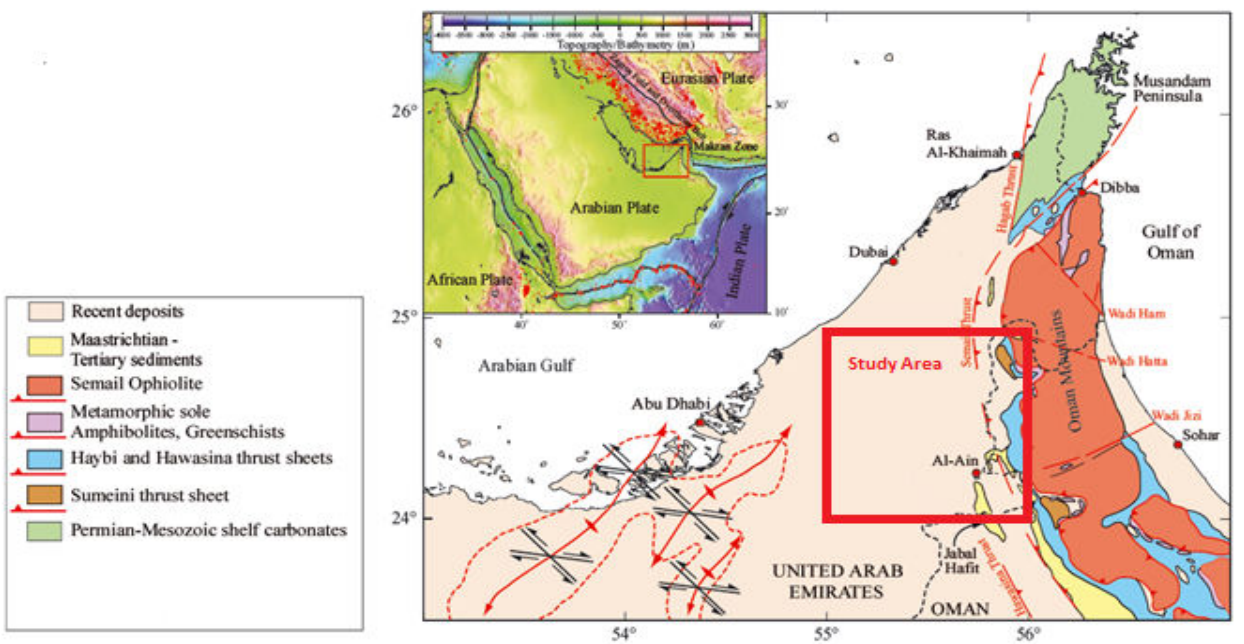

Fig. 1 - Location map and geology of the study area.

The hydrogeological framework for the Eastern part of Abu Dhabi Emirate where the study area is part of it derived from previous theses done by United Arab Emirates University students and reports can be summarized in Table 1 .

The unconsolidated aquifers are the dominant hydrogeologic feature in the study area. These aquifers are the most common and productive aquifers and consist of recent sand dunes and alluvial deposits of various ages (Fig. 2). As mentioned earlier, together, the deposits contain the surficial aquifers of Abu Dhabi Emirate or commonly termed, the shallow, unconfined aquifer. In the study area, the shallow aquifer is comprised of the following units:

- SAU Quaternary sand and gravel aquifer underlain by the Upper Fars Formation as a basal unit.

- SAM Quaternary sand and gravel aquifer underlain by tectonically emplaced dark Marlstones and shales as main basal unit.

- SAJ Quaternary sand and gravel aquifer east of Jebel Hafit (Al Jaww Plain), underlain by Upper Fars and Lower Fars Formations as basal unit.

Table 1 - Hydrogeologic framework of Abu Dhabi (National Drilling company, written communication, 1998).

\begin{tabular}{|c|c|c|c|}
\hline Age & Geologic Sequence & $\begin{array}{l}\text { Approximate } \\
\text { Thickness (m) }\end{array}$ & Hydrogeologic Unit \\
\hline \multirow{2}{*}{ Quaternary } & Eolian sand & 25 & Unsaturated overburden \\
\hline & Alluvium & 30 & \multirow{2}{*}{ Surficial aquifer system } \\
\hline Pliocene-Miocene & $\begin{array}{l}\text { Post-Fars } \\
\text { Upper Fars }\end{array}$ & 200 & \\
\hline $\begin{array}{l}\text { Miocene- } \\
\text { Oligocene } \\
\end{array}$ & $\begin{array}{l}\text { Lower Fars Fm. } \\
\text { Asmari Formation }\end{array}$ & 500 & \multirow{3}{*}{ Basal confining system } \\
\hline $\begin{array}{l}\text { Paleocene - } \\
\text { Eocene }\end{array}$ & $\begin{array}{c}\text { Dammam Formation } \\
\text { Rus Formation } \\
\text { Umm er-Radhuma } \\
\text { Fm }\end{array}$ & 1,200 & \\
\hline Cretaceous & $\begin{array}{l}\text { Simsima formation } \\
\text { Qahlah Formation } \\
\text { Juweiza Formation }\end{array}$ & 3,000 & \\
\hline
\end{tabular}


The water table in the surficial aquifer system generally slopes westward from 60 to $400 \mathrm{~m}$ above sea level at the Oman-Abu Dhabi Emirate boundary north of Al Ain city. The average westward gradient, based on $100 \mathrm{~m}$ of head change over $30 \mathrm{Km}$ of distance is 0.0064 .

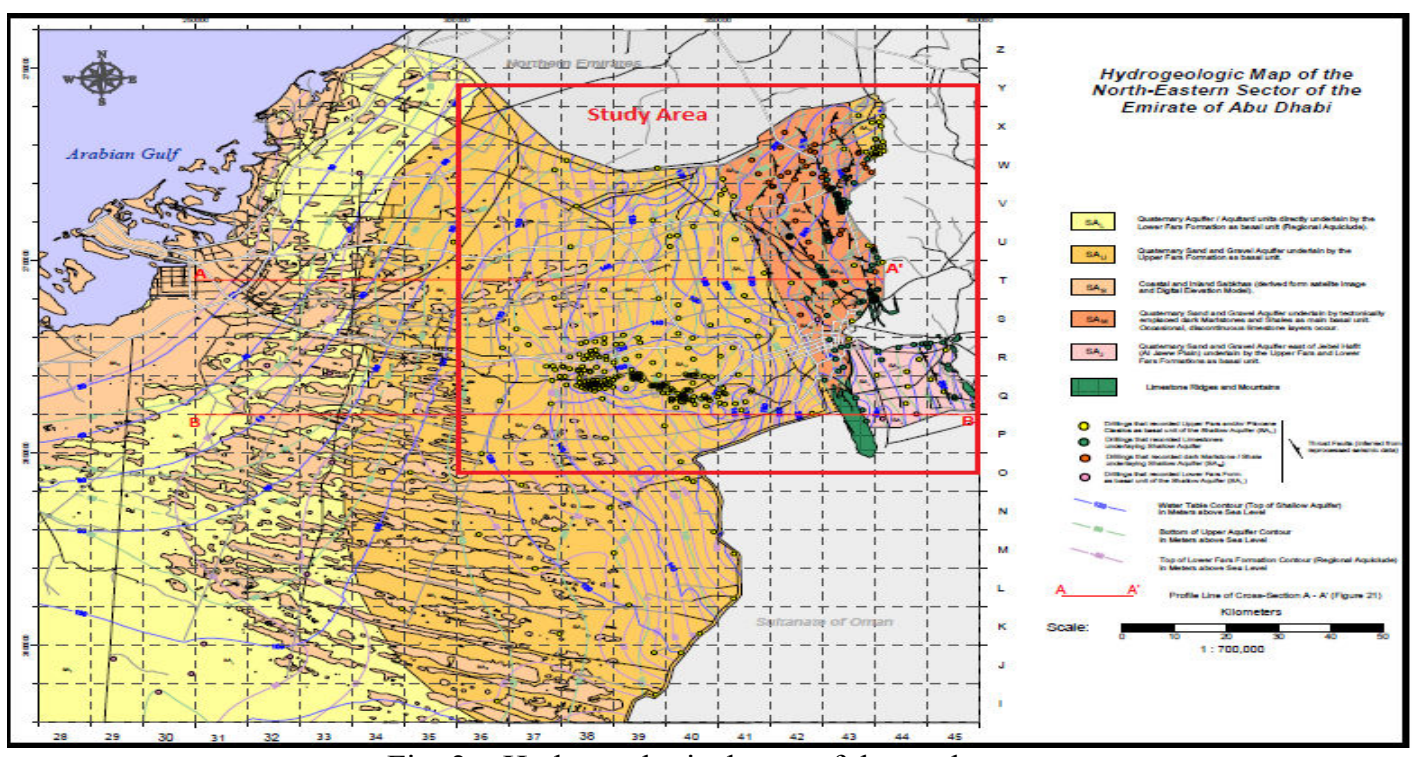

Fig. 2 - Hydrogeological map of the study area.

The catchment in the study area is characterized by a combination of E-W compound linear dunes reaching $60 \mathrm{~m}$ high hydrologically signifying various surficial alluvial and sand aquifers with limited bedrock groundwater potential and alluvial fans, gravel plains signifying active recharge/runoff in wadis with considerable bedrock groundwater potential.

The mean annual precipitation in the study area is about $30 \mathrm{~mm} / \mathrm{yr}$ with a mean annual evapotranspiration of $3900 \mathrm{~mm} / \mathrm{yr}$. As a result of the very high evapotranspiration rates, which exceed the amount of rainfall has a negative water balance on a mean annual basis, i.e. the amount of water gained from precipitation $(\mathrm{P})$ smaller than the loss into the atmosphere by evapotranspiration (ET) $(\mathrm{P}-\mathrm{ET}<0)$. Aquifer recharge is attributed to three sources. Rainfall contributes 5 $\mathrm{mm} / \mathrm{yr}$, Hafit mountain $2 \mathrm{~mm} / \mathrm{yr}$ and wadi flows which originate from Oman mountains $5 \mathrm{~mm} / \mathrm{yr}$, though often active after heavy rainfall, the flatter topography of the Emirate reduces the flow velocity significantly.

\section{GROUNDWATER MODELLING}

In this study, Visual Modular Three-Dimensional Finite-Difference Groundwater Flow Model (MODFLOW) version 4.2 was used. MODFLOW is a mathematical model simulating the groundwater flow through heterogeneous, porous media. In MODFOW three-dimensional groundwater flow is described by the partial differential equation:

$\partial \frac{\partial}{\partial x}\left(k_{x x} \frac{d h}{d x}\right)+\partial \frac{\partial}{\partial y}\left(k_{y y} \frac{d h}{d y}\right)+\partial \frac{\partial}{\partial z}\left(k_{g z} \frac{d h}{d z}\right)-W=S_{s} \frac{d h}{d t}$ 
where $k_{x x}, k_{y y}$, and $k_{z z}=$ the hydraulic conductivity along the $\mathrm{x}, \mathrm{y}$, and $\mathrm{z}$ axes that are assumed to be parallel to the major axes of hydraulic conductivity $(\mathrm{L} / \mathrm{T}), \mathrm{h}=$ the potentiometric head $(\mathrm{L}), \mathrm{W}=$ volumetric flux per unit value representing sources and/or sinks of water $(\mathrm{W}<0.0$ for outflow of the groundwater system, $\mathrm{W}>0.0$ for inflow

(T-1), $5_{z}=$ specific storage of porous material (L-1), and ${ }^{t}=$ time (McDonald \& Harbaugh 1984).

Spatial discretization in MODFLOW is achieved by considering real-world aquifers a system of grid cells which are characterized in terms of rows (i), columns (j), and layers (k). Every cell represents a unit of homogenous properties.

Statistically, the following parameters are used in the MODFLOW calibration results:

1. Residual Mean $(\bar{R})$ is a measure of the average Residual value.

2. Absolute Residual Mean $\mathrm{I} \bar{R}_{\mathrm{I}}$ is a measure of the absolute Residual value and provides a better indication of calibration that residual mean.

3. Standard Error of the Estimate ( $S E E$ ) is measure of the variability of the residual around the expected residual value.

4. The Root Mean Squared error (RMS ).

5. Normalized Root Mean Squared is the RMS divided by the maximum difference in the observed head values and is more representative measure of the fit than the standard RMS, as it accounts for the scale of the potential range of data values.

6. The Correlation Coefficient ( $\operatorname{Cor}$ ) is calculated as the covariance ( $\operatorname{Cov}$ ) between the calculated results $\left(K_{\text {OaI }}\right)$ and the observed results $\left(X_{O b s}\right)$ at selected data points divided by the product of their standard deviations.

\section{Model Setup}

The scope of this study is divided into two parts. In the first part, a steady-state condition is run for a period of ten years to simulate water heads in the whole study area. Whereas, in the second part, a transient-state condition is run to simulate the reasons for the rising water-table in a specified area contained in the study area based on the hydraulic heads generated in the steady-state model. In this study, model specifications are made under the assumption of an isotropic and homogenous aquifer. The model was based on average hydrogeologic conditions published in previous studies and estimates for model parameters are:

Horizontal hydraulic conductivity $\left(\mathrm{K}_{\mathrm{x}}=\mathrm{K}_{\mathrm{y}}\right): 8 \mathrm{~m} / \mathrm{d}$

Vertical hydraulic conductivity $\left(\mathrm{K}_{\mathrm{z}}\right): 2 \mathrm{~m} / \mathrm{d}$

Specific storage $\left(\mathrm{S}_{\mathrm{s}}\right): 0.001$

Specific yield $\left(\mathrm{S}_{\mathrm{y}}\right): 0.15$

Porosity (y): 0.2

The model represents a porous block that is subdivided in MODFLOW in a grid of 476 rows, 439 columns and one layer creating a matrix of 208,964 grid blocks, each $200 \mathrm{~m}^{2}$. Constant-head boundary of $370 \mathrm{~m}$ below the datum was assigned to the eastern part of the model and $110 \mathrm{~m}$ to the western part. The Northern and southern parts represent no-flow boundaries Fig. 3. Recharge to the system was simulated as precipitation $5 \mathrm{~mm} / \mathrm{yr}$, Jabal Hafit $2 \mathrm{~mm} / \mathrm{yr}$ and Oman Mountains $5 \mathrm{~mm} / \mathrm{yr}$. Negative recharge rates were introduced to account for groundwater abstraction used for irrigating the cultivated areas in the study area. 


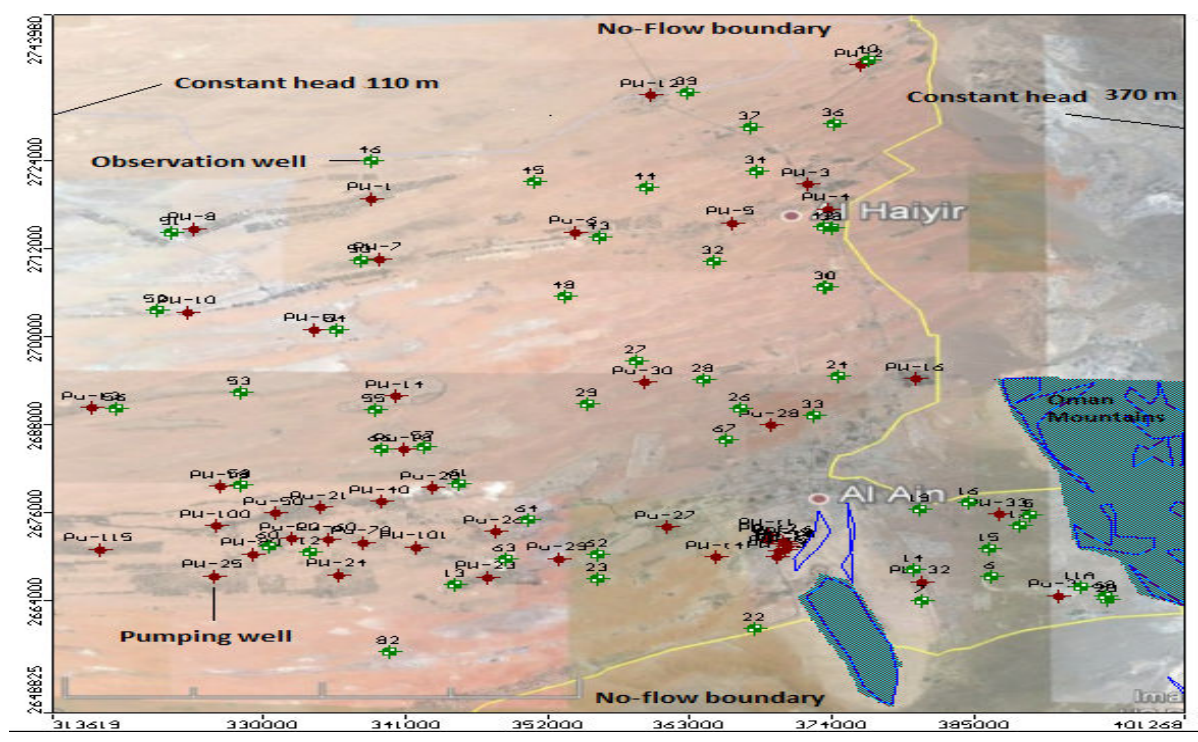

Fig. 3 - Model boundary conditions. The green polygons represent inactive cells in MODFLOW resembling Oman mountains (large green polygon) and Jabal hafit (small green polygon).

Several simulations were run by changing the hydraulic conductivity and recharge rates in order to obtain the best calibration results. Model calibration was based on observation wells data published in previous studies and reports. The simulations were run over a period of 10 years. Fig. 4 shows a simulation result with $\mathrm{Kx}=\mathrm{Ky}=6 \mathrm{~m} / \mathrm{d}, \mathrm{kz}=1.5 \mathrm{~m} / \mathrm{d}$, where calibration is shown in Fig. 5. Whereas, Fig. 6 shows a simulation run with $\mathrm{Kx}=\mathrm{Ky}=8 \mathrm{~m} / \mathrm{d}, \mathrm{Kz}=2 \mathrm{~m} / \mathrm{d}$ while Fig. 7 shows its calibration results.

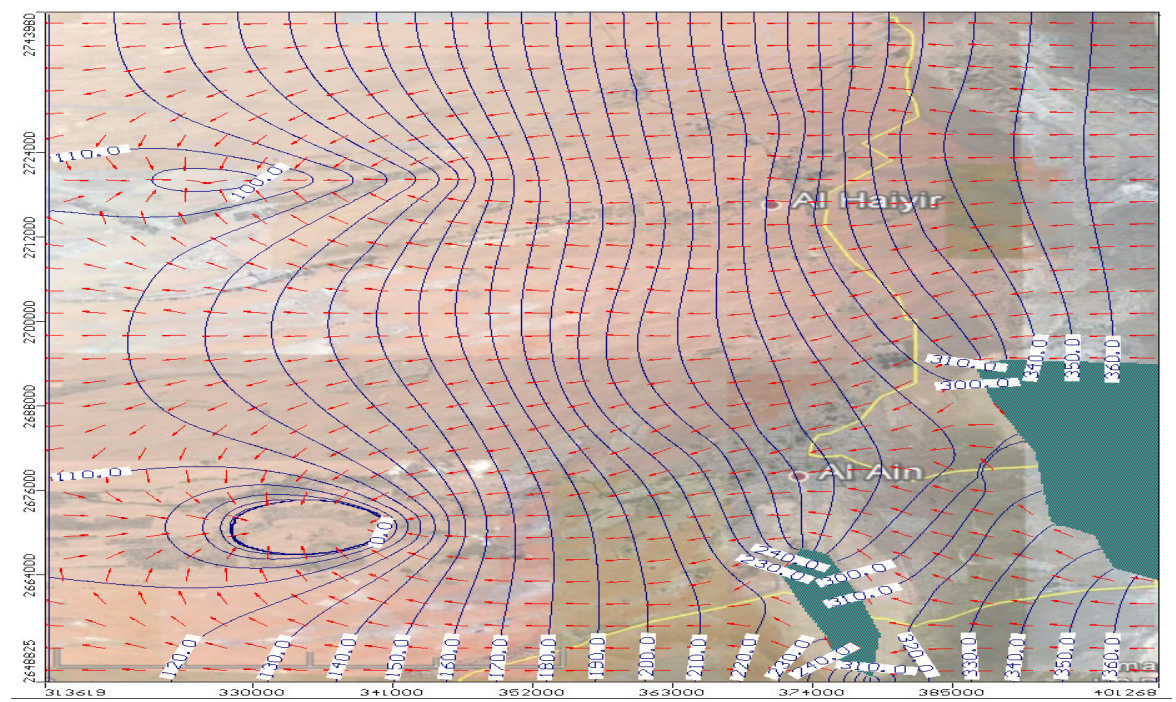

Fig. 4 - Simulated head contours with $\mathrm{Kx}=\mathrm{Ky}=6 \mathrm{~m} / \mathrm{d}, \mathrm{kz}=1.5 \mathrm{~m} / \mathrm{d}$. The red arrows show velocities. 


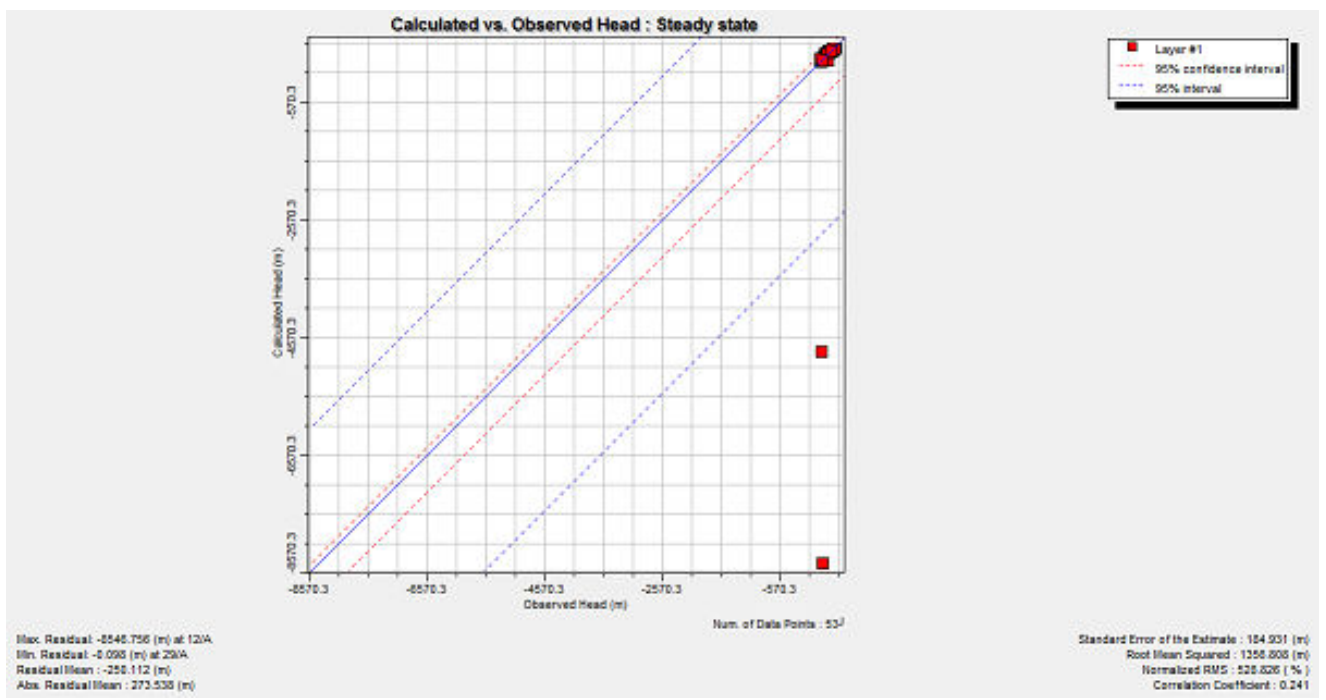

Fig. 5 - Calibration results.

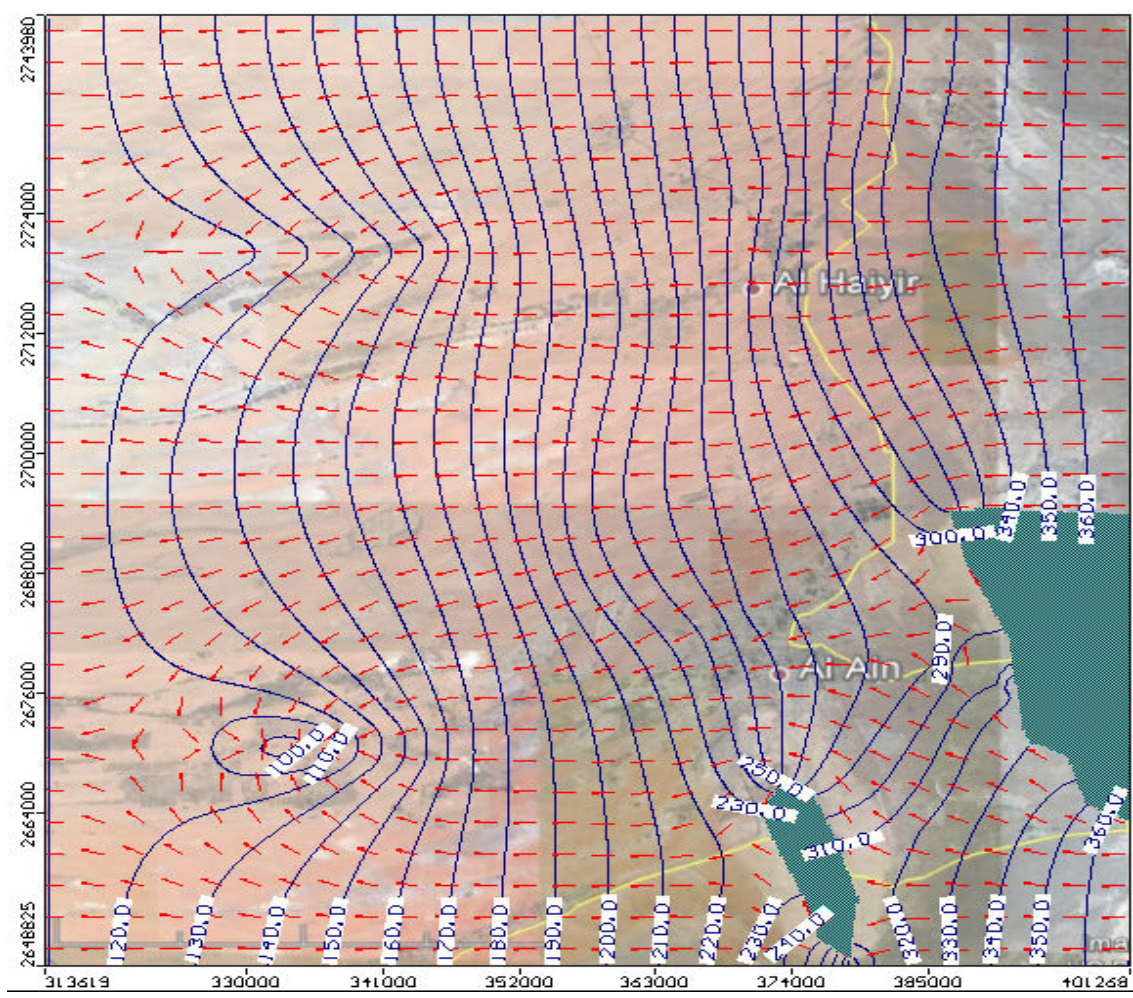

Fig. 6 - Simulated head contours with $\mathrm{Kx}=\mathrm{Ky}=8 \mathrm{~m} / \mathrm{d}, \mathrm{kz}=2 \mathrm{~m} / \mathrm{d}$. The red arrows show velocities. 


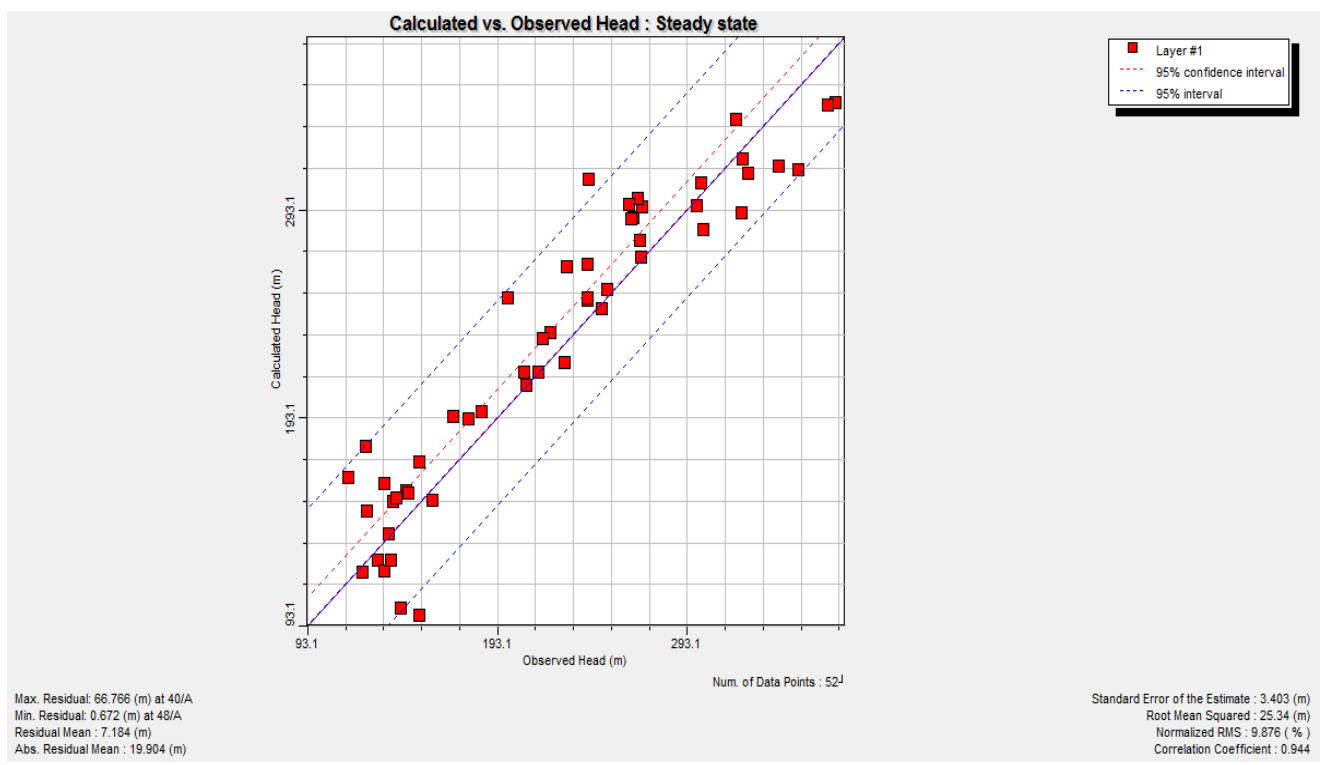

Fig. 7 - Calibration results.

As observed from the calibration results, a horizontal hydraulic conductivity of $8 \mathrm{~m} / \mathrm{d}$ and vertical one of $2 \mathrm{~m} / \mathrm{d}$ resulted in a normalized RMS of $9.8 \%$ and a an Abs. Residual Mean of $19.9 \mathrm{~m}$ compared to a normalized RMS of $528.8 \%$ and an absolute residual mean of $273.5 \mathrm{~m}$ when a horizontal hydraulic conductivity of $6 \mathrm{~m} / \mathrm{d}$ and a vertical one of $1.5 \mathrm{~m} / \mathrm{d}$ were used. Theoretically, a model is considered calibrated when the normalized RMS is $10 \%$. Therefore, the $8 \mathrm{~m} / \mathrm{d}$ and $2 \mathrm{~m} / \mathrm{d}$ for the horizontal and vertical hydraulic conductivities respectively would be used for other simulations with different recharge values. Fig. 8 shows the simulation of heads when the recharge values for Jabal Hafit and Oman mountains were changed from $2 \mathrm{~mm} / \mathrm{yr}$ and $5 \mathrm{~mm} / \mathrm{yr}$ to $4 \mathrm{~mm} / \mathrm{yr}$ and $10 \mathrm{~mm} / \mathrm{yr}$ respectively. Fig 9 shows the calibration results of this simulation.

As noticed from the calibration results when the recharge rates were changed, the Normalized RMS was about $11.2 \%$ and an Abs. Residual Mean of $21.4 \mathrm{~m}$. Comparing these results to the model with recharge rates of $2 \mathrm{~mm} / \mathrm{yr}$ for Jabl Hafit and $5 \mathrm{~mm} / \mathrm{yr}$ for Oman mountains, the Normalized RMS was $9.8 \%$ and an Abs. Residual Mean of $19.9 \mathrm{~m}$ (Fig. 7). As a result, the model with horizontal hydraulic conductivity of $8 \mathrm{~m} / \mathrm{d}$ and vertical one of $2 \mathrm{~m} / \mathrm{d}$ and recharge parameters of $2 \mathrm{~mm} / \mathrm{yr}$ for Jabal Hafit and $5 \mathrm{~mm} / \mathrm{yr}$ for Oman mountains is the most calibrated (Fig. 8 and 9).

\section{SUMMARY AND CONCLUSIONS}

The steady-state simulations were used to validate the input hydrogeologic parameters in terms of hydraulic conductivity, boundary conditions and recharge. Calibration results based on observation wells data showed that the model was considered calibrated with a Normalized RMS error of $9.8 \%$ when the following hydrogeologic parameters were considered: horizontal hydraulic conductivity of $8 \mathrm{~m} / \mathrm{d}$; vertical hydraulic conductivity of $2 \mathrm{~m} / \mathrm{d}$; constant heads of $110 \mathrm{~m}$ in the western boundary of the model and $370 \mathrm{~m}$ in the eastern boundary; precipitation of $5 \mathrm{~mm} / \mathrm{yr}$ and recharge of $2 \mathrm{~mm} / \mathrm{yr}$ for Jabal Hafit and $5 \mathrm{~mm} / \mathrm{yr}$ for Oman mountains. 


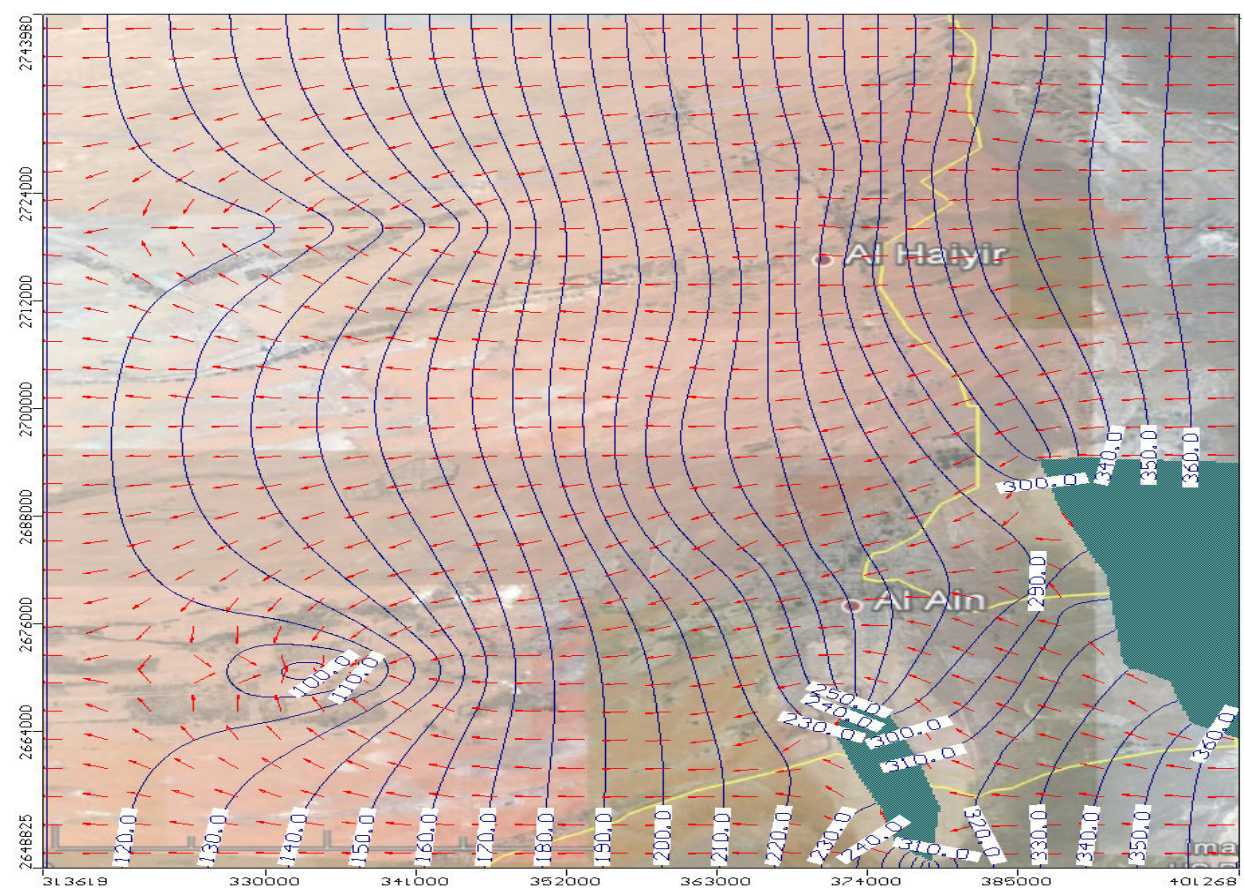

Fig. 8 - Simulated head contours with recharge of $4 \mathrm{~mm} / \mathrm{yr}$ for Jabal Hafit (small green polygon) and $10 \mathrm{~mm} / \mathrm{yr}$ for Oman mountains (large green polygon). The red arrows show velocities.

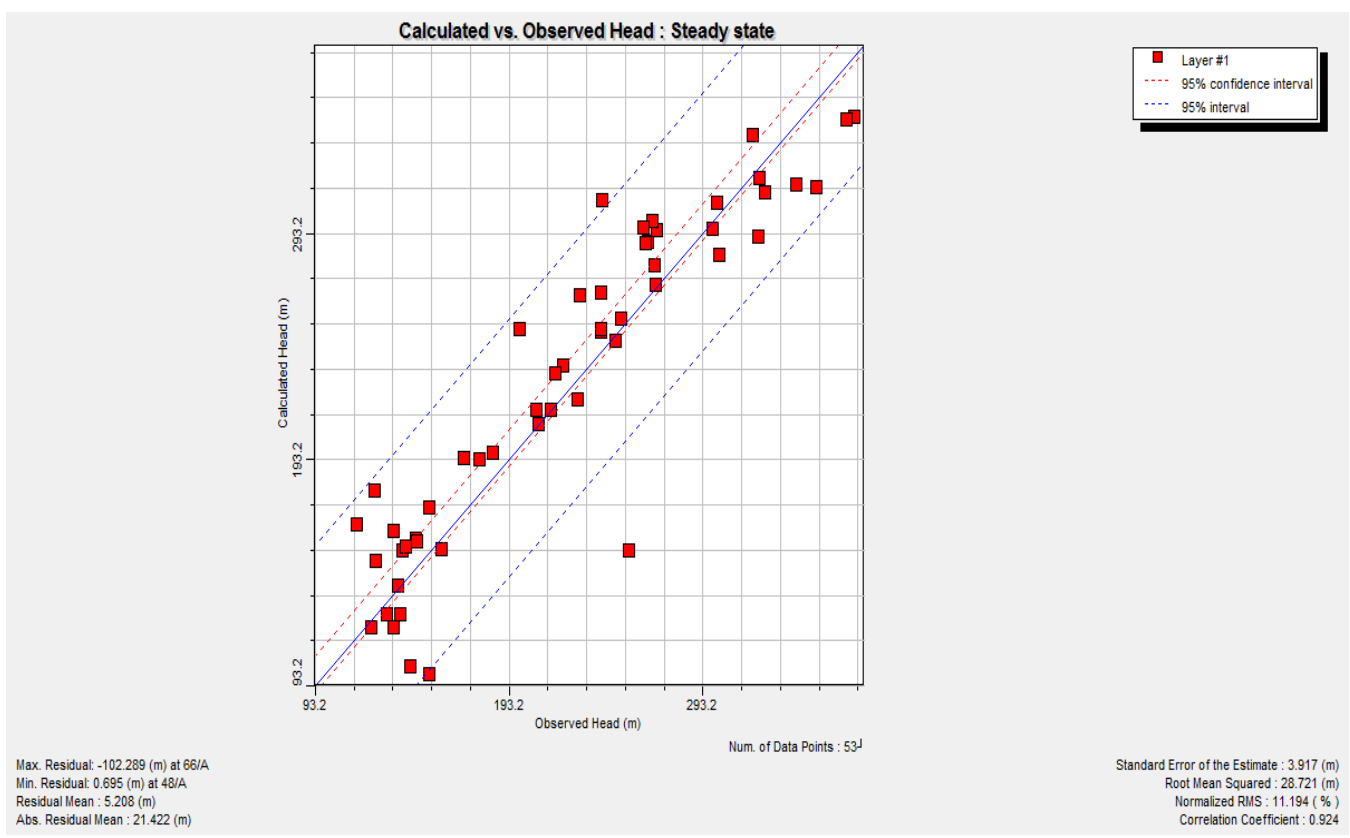

Fig. 9 - Calibration results. 


\section{Reference}

- Alsharhan, A.S., 2001 Hydrogeology of an Arid Region: The Arabian Gulf and Adjoining Areas, Elsevier, New York.

- Brook, M.C, Al Houqani, T. Darawsha, Al Alawneh M., and Achary S., 2006. Groundwater Resources; Development and Management in Abu Dhabi Emirate, UAE. In Proceedings of 3rd Joint UAE-Japan Symposium, Sustainable GCC Environment and Water Resources, EWR, 2006.

- Chowdhury, R. K. and Beecham, S. (2010). Australian Rainfall Trends and Their Relation to the Southern Oscillation Index (SOI), Hydrological Processes24(4):504-514.

- Chowdhury, R. K. and Beecham, S. (2012a) Suitability of a Transitional Probability Matrix Model for Catchment Scale Rainfall Projections, 9th International Workshop on Precipitation in Urban Areas: Urban Challenges in Rainfall Analysis, 6-9 December 2012, St. Moritz, Switzerland, p233-239.

- Chowdhury, R. and Beecham, S. (2012b) Climate Change Impacts on the Hydrology of Aldgate and Inverbrakie Creeks, Water and Climate: Policy Implementation Challenges: Practical Responses to Climate Change National Conference 2012, 1-3 May, National Convention Centre, Canberra, organized by Engineers Australia.

- Environment Agency-Abu Dhabi (2009) Climate Change: Impacts, Vulnerability and Adaptation, Environment Agency-Abu Dhabi, UAE.

- Elmahdy S., and Mohamed, M. Topographic attributes controlling groundwater flow and salinity in Al-Ain, UAE: a prediction method using remote sensing and GIS. Journal of Environment and Earth Science, Vol. 2, No.8, 2012.

- Hydroconsult, 1978, Abu Dhabi (UAE) Eastern Region Water Resources: Reconnaissance Report and Development Proposal, Report for Ministry of Electricity and Water, United Arab Emirates, Emirate of Abu Dhabi, Hydroconsult, Nicosia, Cyprus.

- Imes J.L. and Wood W., 2006. Solute and isotope constraint of groundwater recharge simulation in an arid environment, Abu Dhabi Emirate, United Arab Emirates; Hydrogeology Journal, DOI 10.1007/s10040-007-0177-x.

- Rashid, M. M., Beecham, S., and Chowdhury, R. (2013) Assessment of statistical characteristics of point rainfall in the Onkaparinga catchment in South Australia, Hydrol. Earth Syst. Sci. Discuss., 10, 5975-6017, doi:10.5194/hessd-10-5975-2013, 2013.

- $\quad$ Rizk, Z.S, Garamoon, H.K, El Etr H.A. 1998 Morphometry, surface runoff and flood potential of major drainage basins of Al Ain area, United Arab Emirates. Egypt Journal of Remote Sensing \& Space Sciences. Vol 1, 391-412.

- Sherif, M, Mohamed, M., A. Shetty, and M. Almulla. Rainfall-Runoff Modeling of Three Wadis in the Northern Area of UAE, J. Hydrologic Eng. (ASCE) Volume 16, Issue 1, pp. 10-20, $2011 \mathrm{a}$.

- Sherif, M, Mohamed, M., A. Kacimov, and A. Shetty. Assessment of groundwater quality in the northeastern coastal area of UAE as precursor for desalination, Desalination, 273 (1-2) 436-446, $2011 b$.

- Sherif M, Akram S, Shetty A. 2009. Rainfall analysis for the northern wadis of United Arab Emirates. Journal of Hydrologic Engineering 14(6): 535-544.

- Sherif, M., Mohamed, A., Shetty, A. and Chowdhury, R. K. (2013) Analysis of Rainfall, PMP and Drought in United Arab Emirates, International Journal of Climatology, DOI: $10.1002 /$ joc. 3768 .

- Ministry of Energy - UAE (2006) Initial National Communication to the United Nations Framework Convention on Climate Change, Ministry of Energy, UAE. 